\title{
Adhesion and Proliferation of Osteoblastic Cells on Hydroxyapatite-dispersed Ti-based Composite Plate
}

\author{
MASAHIKO KOBAYASHI ${ }^{1}$, SHOICHI NIHONMATSU ${ }^{2}$, TAKAHIRO OKAWARA ${ }^{2}$, HIROYUKI ONUKI ${ }^{1}$, \\ HIROSHI SAKAGAMI ${ }^{3}$, HIROSHI NAKAJIMA ${ }^{4}$, HIROYUKU TAKEISHI ${ }^{2}$ and JUN SHIMADA ${ }^{1}$ \\ ${ }^{1}$ Division of First Oral and Maxillofacial Surgery, Meikai University School of Dentistry, Sakado, Japan; \\ ${ }^{2}$ Chiba Institute of Technology, Department of Mechanical Science and Engineering, Chiba, Japan; \\ ${ }^{3}$ Meikai University Research Institute of Odontology (M-RIO), Sakado, Japan; \\ ${ }^{4}$ Division of Dental Biomaterials Science, Meikai University School of Dentistry, Sakado, Japan
}

\begin{abstract}
Background/Aim: Biocompatibility of a novel and more stable hydroxyapatite (HA)-dispersed titanium (Ti)-based composite was investigated, using the mouse osteoblast precursor cell line MC3T3-E1. Materials and Methods: Surface of powders and plates was observed by scanning electron microscopy. Distribution of calcium and phosphorus on the surface of the composite was evaluated by an electron beam microanalyzer. Crystal structure was analyzed by $X$-ray diffractometer. Cell viability was determined by WST-1 assay. Results: HA was stable against the compressive force, shearing stress and sintering heat at $800^{\circ} \mathrm{C}$, but it slightly decomposed at $1100^{\circ} \mathrm{C}$. With the increase of $\mathrm{HA}$ in the composites, the adhesion/proliferation of MC3T3-E1 cells was reduced. The growth inhibition by HA does not seem to be due to materials released from the plate, but rather to the contact to the surface of the plate. Sintering of the HA plate at $1100^{\circ} \mathrm{C}$ increased the number of attached viable cells. On the other hand, culturing on the synthesized calcium phosphate (apatite containing carbonic acid) increased the number of attached cells to a greater extent. Conclusion: $H A$ inhibits the growth of osteoblastic cells, but sintering at $1100^{\circ} \mathrm{C}$ changes the surface properties of the composite so as to stimulate cell growth.
\end{abstract}

This article is freely accessible online.

Correspondence to: Masahiko Kobayashi, Division of First Oral and Maxillofacial Surgery, Meikai University School of Dentistry, 1-1 Keyakidai, Sakado, Saitama 350-0283, Japan. Tel: +81 492792758, e-mail: masahiko.kobayashi@dent.meikai.ac.jp; sakagami@dent.meikai.ac.jp

Key Words: Hydroxyapatite, titanium, composite, osteoblast, proliferation, biocompatibility.
Various biomaterials are used as substitutes for restoring the morphology and function of tissues and organs of the human body $(1,2)$. Among them, dental implants have been widely used to achieve functional and aesthetic recovery of tooth defects (3). Recent progress in the material and biological science changed our attention from brass and copper to elemental metals such as $\mathrm{Co}-\mathrm{Cr}, \mathrm{Ti}, \mathrm{Zr}$, their alloys and ceramics. Since the discovery of direct binding of bone and Ti without intervening fibrous connective tissue (now defined as osseointegration) (4), Ti has become the mainstream of dental implants. Among dental materials, Ti and HA have been the most popular, and the surface of Ti has been treated to improve the affinity to bone (1-3). Subsequent histological analysis revealed that $\mathrm{Ti}$ implants directly contact the bone tissue in a layer of amorphous structure. Immunoelectron microscopic analysis demonstrated that the amorphous structure with an approximate diameter of $50 \mathrm{~nm}$ contains collagen fibril layer (5) and proteoglycans (6), allowing smooth contact of $\mathrm{Ti}$ to the bone. On the other hand, bioactive ceramics were used as an implant material by sintering the fine super powder of artificial apatite, similarly to the bone and tooth inorganic components in 1970 (7). Upon implantation of the bioactive ceramics of HA into the body, a fine particle layer of HA that contains carbonate ion, but lacks calcium forms on the surface, and becomes the connector to the bone. Apatite formed on the surface bonds to HA (an inorganic component of bone and teeth) via osteoblasts that actively proliferate on the surface and produce new bone. Although fibrous connective tissue does not exist around the implant, the implant directly binds to the bone (8). Therefore, in order to achieve the initial fixation of the implant, pure $\mathrm{Ti}$ or Ti alloy has been coated with HA that has high osseointegration capability (9). A composite material of Ti coated with a thin layer of HA is now available. However, HA is easily detached from the coated layer (10, 11). We thought that dispersion of HA to the interior of $\mathrm{Ti}$ may stabilize the composite material, and manufactured an 
HA-dispersed Ti-based composite (Ti/HA) material by a compression shear method.

In the present study, we first investigated the surface of Ti/HA using an electron probe microanalyzer (EPMA), the distribution of calcium and phosphorus by EPMA, the crystal structure during the preparation steps by an X-ray diffractometer (XRD), and then the biocompatibility of Ti/HA, based on the adhesion/proliferation of mouse osteoblast precursor cell line MC3T3-E1.

\section{Materials and Methods}

Preparation of HA-dispersed Ti-based composite (Ti/HA). Ti powder (grain size of $45 \mu \mathrm{m}$ or less and purity $99.9 \%$ ) and HA powder (Taihei Chemical Industry Co., Ltd., Osaka, Japan) having a particle diameter of 5 to $20 \mu \mathrm{m}$ were used as the sample powder. Ti and HA composite powders were prepared by mixing $\mathrm{Ti}$ (base material) and HA powder at the volume content ratio of $0,5,7.5$ and $10 \%$ in a powder mixer for $6 \mathrm{~h}$. The sample powder was then filled on a pressure receiving plate of a compression shearing device in an arbitrary filled shape to make a thickness of $2.5 \mathrm{~mm}$, and applied a compressive load of 500 MPa via a pressing plate by rotating the screw. Thereafter, by moving the pressure plate to the horizontal direction under the compressive load, the sample powder was shear-deformed and solidified. The shear distance was $5 \mathrm{~mm}$. The compressive load was measured using a strain gauge (Type KFG-2-120-C1-11 L1 M2 R: Kyowa Denshi, Tokyo, Japan) connected to the load axis by a 4-gauge method.

Sample powder was solidified by compressive shear at ambient temperature and atmosphere, and thus the prepared Ti/HA material was sintered to firmly bond to Ti powder in an electric tube furnace under an argon atmosphere. The temperature was raised to the sintering temperature at an elevation rate of $10^{\circ} \mathrm{C} / \mathrm{min}$, held for $1 \mathrm{~h}$ and then cooled. The sintering temperature was $1373 \mathrm{~K}\left(1100^{\circ} \mathrm{C}\right)$, at which temperature HA is thermally stable. In order to prevent its oxidation during sintering, Ti was wrapped with tantalum foil. Ti sponge was used to suppress the oxidation by absorbing the oxygen in the air at high temperature.

In this study, the following three typical plates were used: Ti/HA plate (HA volume content 0, 5, 7.5, 10 vol.\%), a Ti plate (Ti 99.5\%, Grade I, Tokuriki-honten, Tokyo, Japan) and a cell disinfecting plastic dish (Becton Dickinson Falcon, NJ, USA) (control) (size: 10 $\mathrm{mm} \times 10 \mathrm{~mm} \times 1.5 \mathrm{~mm})$. These plates were polished by a polishing apparatus (Alpha Beta \& Vector Grinder-Polishers and Power head, 60-1990, Buehler, IL, USA): initially by abrasive buff (Tex Met 2500: Buehler), polishing agent (Suspension Cylinder, $9 \mu \mathrm{m}$ : Buehler), an abrasive (suspension, $3 \mu \mathrm{m}$ : Buehler), polishing buff (Tex Met 1500: Buehler), and finally by polishing buff (mastertex), with an oxide polishing agent (aluminum oxide liquid abrasive, master prep, $0.05 \mu \mathrm{m}$ : Buehler).

The polished plate was washed with $70 \%$ ethanol for $10 \mathrm{~min}$ and then with an ultrasonic washer (TOCHO, UC-0515: Ueno Seisakusho, Tokyo, Japan) for $10 \mathrm{~min}$. It was rinsed dry with ultrapure water, autoclaved and used for cell culture experiments.

Surface analysis. Distribution of calcium and phosphorus, the main components of $\mathrm{Ti}$ and $\mathrm{HA}$, on the surface of the $\mathrm{Ti} / \mathrm{HA}$, was evaluated by electron probe microanalyzer (EPMA, JXA-8800: JEOL, Tokyo, Japan). When element concentration was elevated, the color changed from bluish to red.
Qualitative analysis. In order to evaluate whether or not the crystal structure of HA has changed due to the compressive load, shear force and sintering heat during the preparation of Ti/HA material plate, qualitative analysis was performed using an X-ray diffractometer (XRD, RINT-2100: JEOL). The standard waveform (ICDD) of HA is represented in red.

Surface observation. The surface of Ti powder, HA powder and plates was observed using a scanning electron microscope (SEM, JSM-6360LV: JEOL). The morphology of proliferating cells on each plate was observed after washing with PBS (-), fixing with $2 \%$ glutaraldehyde and vacuum evaporation (200 ̊̊) of deposited Au.

Cell culture. Osteoblast precursor cell line MC3T3-E1 derived from the C57BL/6 mouse calvarial (DS Pharma Biomedical Co., Ltd., Osaka, Japan) was cultured at $37^{\circ} \mathrm{C}$ in a $5 \% \mathrm{CO}_{2}$ incubator under humidified atmosphere in alpha minimum essential medium $(\alpha-$ MEM: GIBCO BRL, NY, USA) supplemented with $10 \%$ fetal bovine serum (FBS: Nichirei Biosciences Inc., Tokyo, Japan), penicillin $\mathrm{G}$ potassium (100 units/ml: Meiji Seika Pharma Co., Ltd., Tokyo, Japan) and streptomycin sulfate $(100 \mu \mathrm{g} / \mathrm{ml}$ : Meiji Seika). Cells were detached with $0.25 \%$ trypsin (Sigma-Aldrich, St. Louis, MO, USA) and $0.025 \%$ EDTA (Wako Pure Chemical Industries, Ltd., Osaka, Japan).

Reagents. WST-1 (Cell Counting Kit: Dojin Chem. Laboratory, Co. Ltd., Kumamoto, Japan) was used for cell counting. Fibronectin (Sigma-Aldrich) was used at $25 \mu \mathrm{g} / \mathrm{ml}$ to stimulate cell adhesion. In addition, superoxide dismutase (SOD) (Sigma-Aldrich) was used at a final concentration of $300 \mathrm{units} / \mathrm{ml}$ to scavenge superoxide $\left(\mathrm{O}_{2}^{-}\right)$ generated in the solution.

Cell proliferation assay. MC3T3-E1 cells were inoculated at $4 \times 10^{4}$ cells/ml $(750 \mu \mathrm{l})$ in a 24 -well cell culture plate (Becton Dickinson Falcon, NJ, USA). After $72 \mathrm{~h}$, coverslips on which the cells were attached were taken by tweezers and transferred to a new 24-well plate, and fresh culture medium $(825 \mu \mathrm{l})$ containing WST-1 solution $(75 \mu \mathrm{l}$ ) was added (IV in Figure 1A). After incubation for $1.5 \mathrm{~h}$, aliquots $(100 \mu \mathrm{l})$ of the culture medium supernatant were transferred to a 96-microwell plate (Becton Dickinson), and the absorbance at $450 \mathrm{~nm}$ of water-soluble formazan produced by WST-1 reduction by intracellular dehydrogenase was measured by a microplate reader (Multiskan Bichromatic, Dainippon Pharmaceutical, Tokyo, Japan). The control group is shown as $100 \%$ (Figure 1A).

Statistical analysis. Columns and bars in the graph of the proliferation activity of cultured cells show the mean value and standard error. Significant differences between the two groups were tested using Student's $t$-test. A value of $p<0.05$ was considered to be significant.

\section{Results}

Characteristics of HA-dispersed Ti-based composite. We confirmed that application of compressive load (500 MPa) and shear stress (distance 1 to $10 \mathrm{~mm}$ ) did not affect the properties of HA, judging from the pattern of HA's standard waveform (red) in the X-ray diffraction (Figure 2A). We also found that sintering of $\mathrm{HA}$ at $1073 \mathrm{~K}\left(800^{\circ} \mathrm{C}\right)$ for 1 to $5 \mathrm{~h}$ did not change the waveforms, whereas elevation up to 1373 


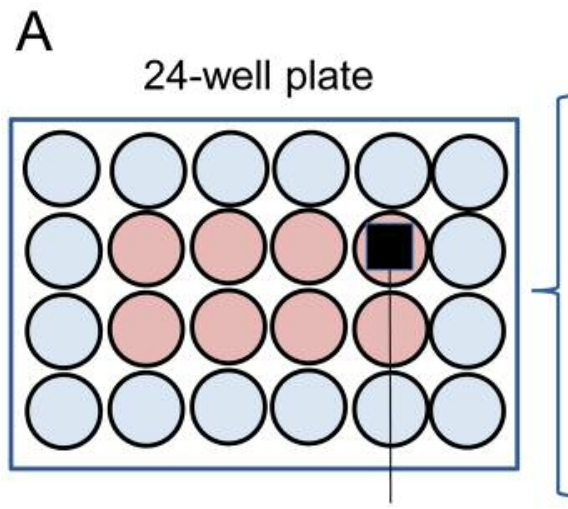

Plate
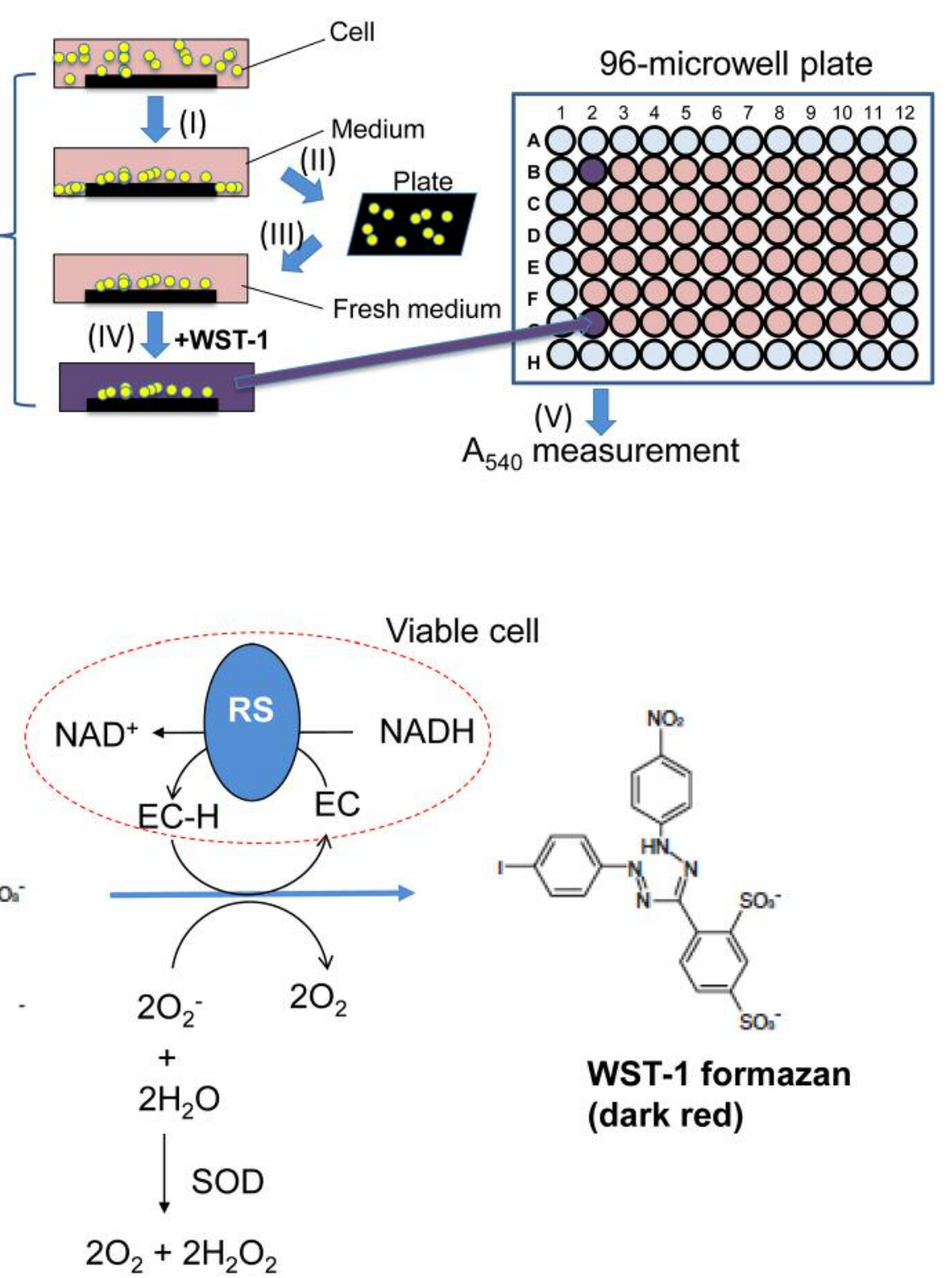

Figure 1. Determination of viable cell number on the plate. MC3T3-E1 cells were inoculated on coverslips in 24-well plate (I). Coverslips on which the cells were attached were taken by tweezers (II) and transferred to a new 24 well plate and fresh culture medium containing WST-1 solution was added (IV). Aliquots of the culture medium supernatant were transferred to a 96-microwell plate, and the absorbance at $450 \mathrm{~nm}$ was determined (A). The principle of WST-1 assay is shown in (B). WST-1 simultaneously detects not only viable cells but also $\mathrm{O}_{2}^{-}$, present in the culture medium. $E C$ represents electron-binding reagent. $R S$ represents mitochondrial succinate-tetrazolium reducing system.

$\mathrm{K}\left(1100^{\circ} \mathrm{C}\right)$ changed it partially, suggesting some material alteration in the characteristics of HA (Figure 2B).

The distribution of calcium and phosphorus, which are the main components of HA, on the surface of the Ti/HA plate was evaluated by EPMA surface analysis (Figure $3 \mathrm{~A}$ and $\mathrm{B}$ ). With the increase in the HA content, the occupancy of HA was increased in the plate surface, whereas the occupancy of Ti was reduced, judging from the color (Figure 3A). The color of the surface of $100 \%$ Ti plate was not pure red
(Figure 3A), possibly due to the problem of the measurement by the beam scanning. With the increase of HA, the ratio of phosphorus, but not of calcium, was increased (Figure 2), possibly due to the low sensitivity of measurement.

Effect of $\mathrm{O}_{2}^{-}$on WST-1 measurement of cell growth. Evaluation of the relative viable cell number by WST-1 method should be performed carefully (12). This method is based on the cleavage of tetrazolium salt to formazan by 

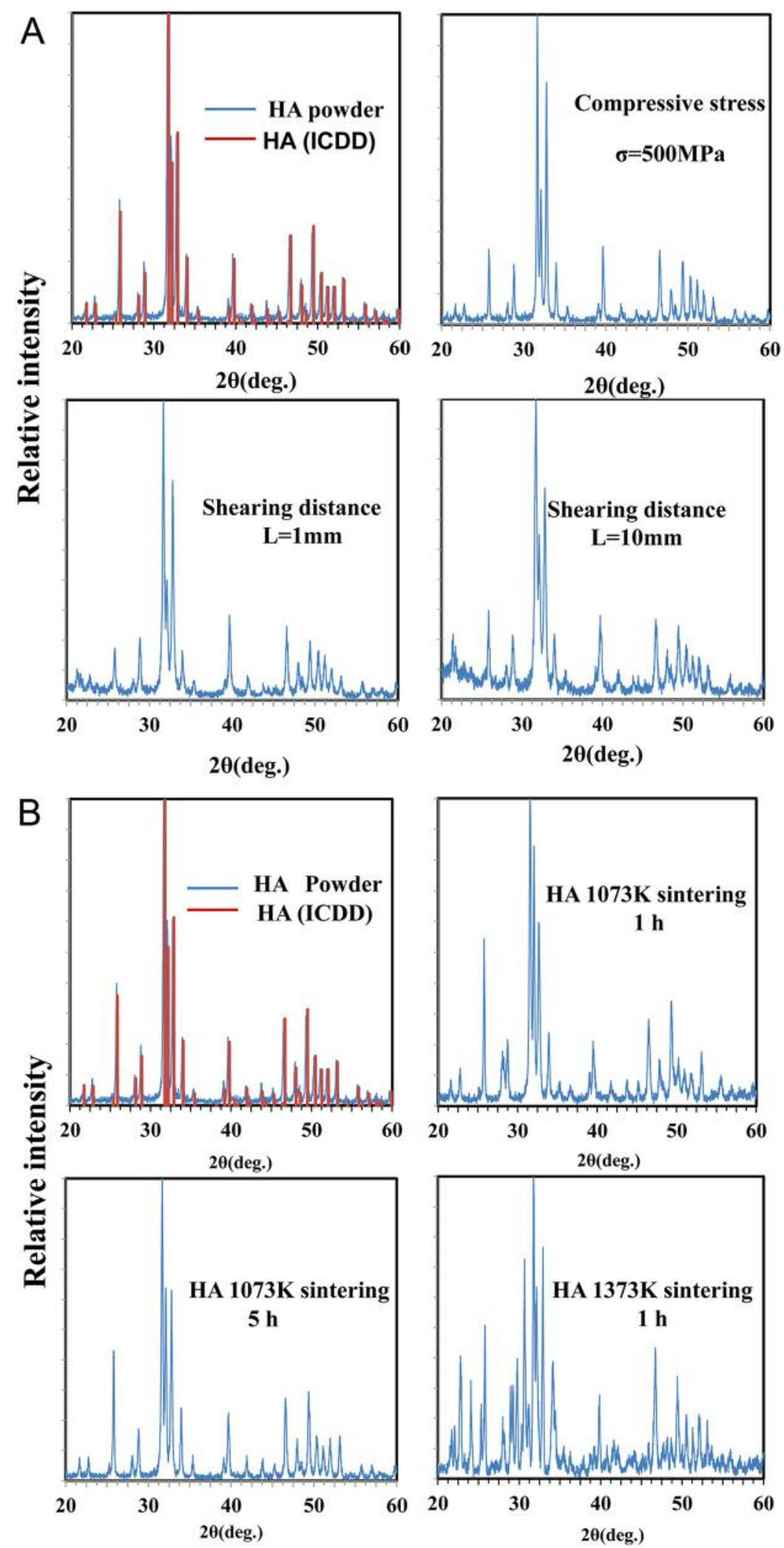

Figure 2. Analysis of hydroxyapatite (HA) by the X-ray diffraction (XRD). (A) Upper left panel represents the chart of HA powder. Red chart represents the standard of HA (ICDD). Upper right panel indicates the effect of compressive force stress (500 MPa). Lower panels indicate the effect of shearing stress. (B) Panels indicate the effect of sintering temperature (1073 K and $1373 \mathrm{~K})$. 

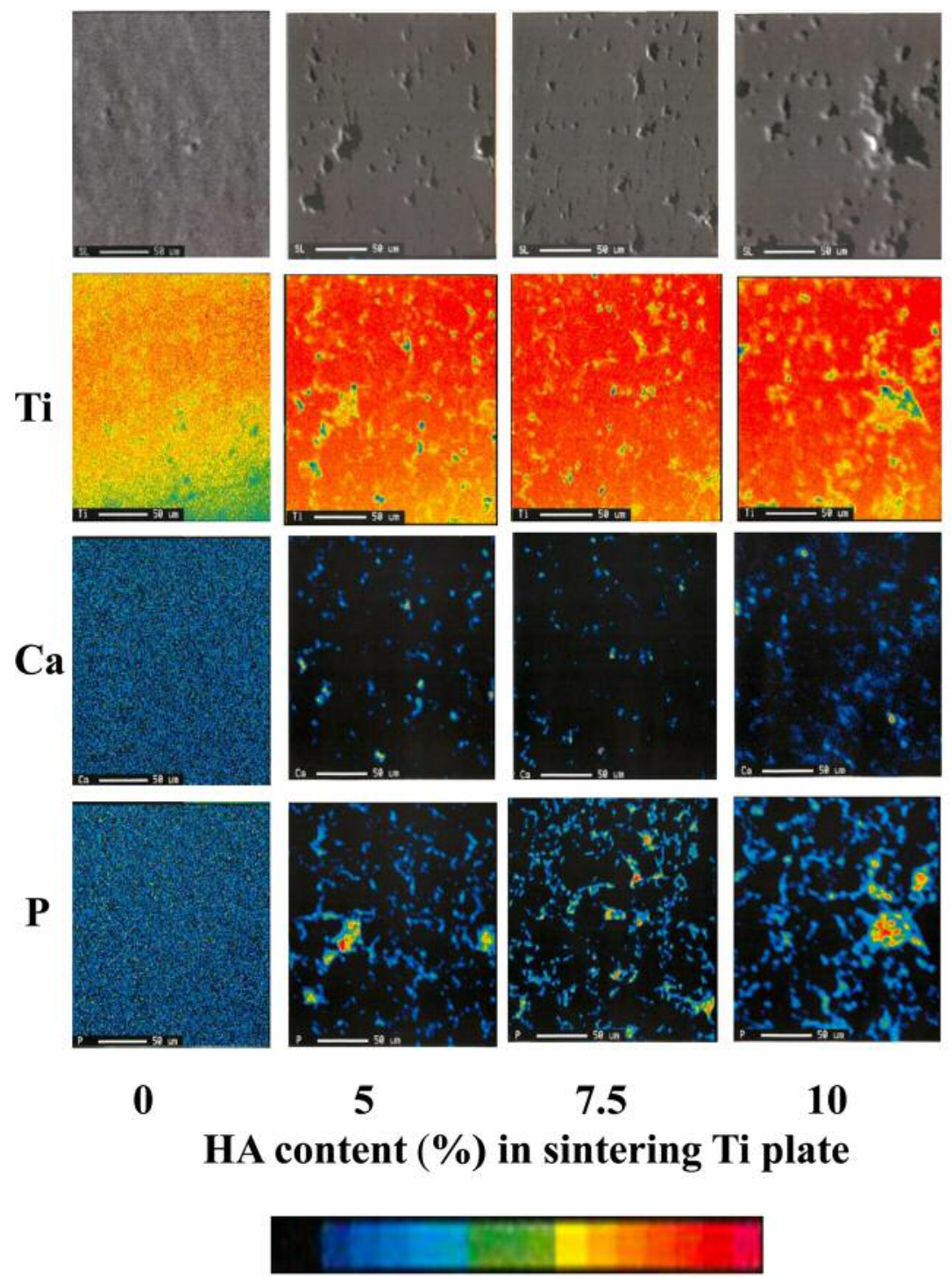

Figure 3. Area analysis of titanium materials containing hydroxyapatite by electron probe microanalyzer (EPMA). (First row) The surface image of sintering Ti plate containing HA. (Second row) Ti distribution image in the materials. (Third row) Ca distribution image in the materials. (Fourth row) $P$ distribution image in the materials.

mitochondrial succinate-tetrazolium reductase (EC1.3.99.1). The absorbance intensity of the purple color generated by dehydrogenase reaction is directly proportional to the number of living cells (Figure 1B). The formazan dye produced by viable cells can be quantified by a microplate reader by measuring the absorbance of purple color at $450 \mathrm{~nm}$. However, WST-1 also reacts with $\mathrm{O}_{2}^{-}$present in the culture medium to generate WST-1 formazan (13) (Figure 1B). Thus, it is difficult to accurately determine the number of viable cells in the presence of high $\mathrm{O}_{2}{ }^{-}$concentration. Therefore, it was necessary to add SOD to scavenge $\mathrm{O}_{2}{ }^{-}$for the accurate determination of viable cell number (Figure 1B).
The effect of $\mathrm{O}_{2}{ }^{-}$on the determination of viable cell number was first examined, by adding SOD to the culture (Figure 4A). When SOD (300 units/ml) was added at the time of viable cell determination with WST-1, the absorbance at $450 \mathrm{~nm}$ was reduced by approximately $32 \%$, indicating the production of significant amount of $\mathrm{O}_{2}^{-}$during culture. However, when cells were pretreated for $72 \mathrm{~h}$ with SOD to completely scavenge $\mathrm{O}_{2}^{-}$ during culture, additional treatment with fresh SOD did not further reduce the absorbance value (right panel in Figure 4A). This suggests that the relative viable cell number can be accurately determined by the WST- 1 method in the presence of SOD. Addition of SOD did not alter the cell morphology 


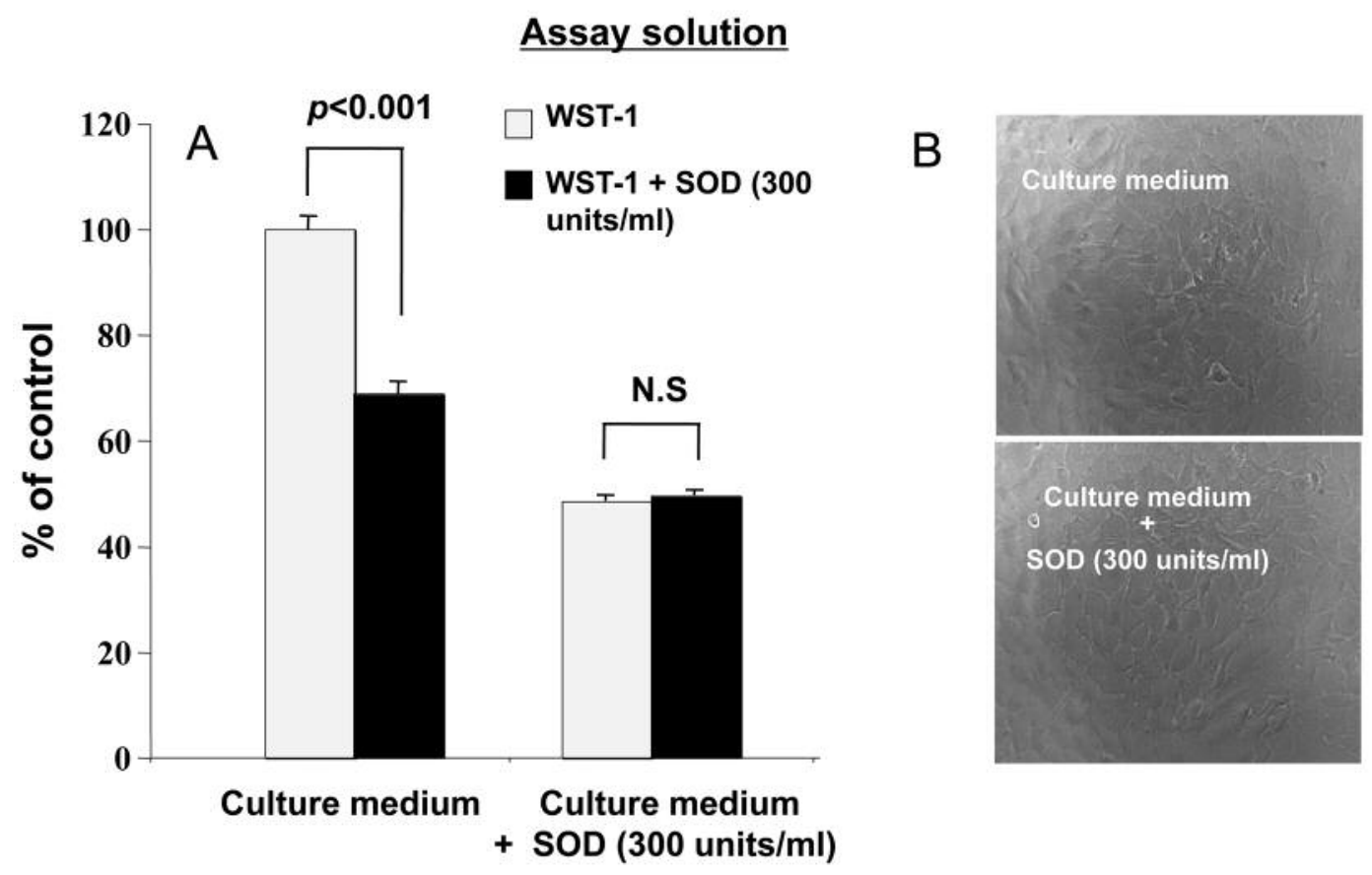

Figure 4. Effect of $\mathrm{O}_{2}^{-}$on the evaluation of MC3T3-E1 cell proliferation by the WST-1 assay. MC3T3-E1 cells $\left(4 \times 10^{4}\right.$ cells $\left./ \mathrm{ml}\right)$ were incubated at $37^{\circ} \mathrm{C}$ in $5 \% \mathrm{CO}_{2}$ for $72 \mathrm{~h}$. (A) White column represents the results of the WST-assay in untreated MC3T3-E1. The mean absorbance value of this assay was represented as $100 \%$. Black column represents the results of the WST-1assay in MC3T3-E1 cells treated with superoxide dismutase $(S O D ; 300$ units $/ \mathrm{ml})$. Right columns represent the results of the assay in MC3T3-E1 cells cultured with SOD (300 units/ml). Values are mean $\pm S E$ for 8 wells. (B) Phase contrast image of cultured MC3T3-E1 cells, showing undistinguishable morphology between a normal culture and the culture added with $S O D$.

(Figure 4B). Therefore, evaluation of the proliferation of MC3T3-E1 cells on Ti/HA plates was carried out in the presence or absence of SOD into the culture medium.

Effect of pure and sintering of Ti plate on cell growth. MC3T3-E1 cells were cultured on pure Ti plates and sintered Ti plates and their proliferation was compared (Figure 5). SEM observation showed no difference of cell morphology between pure and sintered plates, even when cell adhesion was enhanced by fibronectin coating (Figure 5A). Furthermore, viable cell number, measured by WST-1 method, showed no significant difference between these two plates (Figure 5B).

Proliferation on Ti/HA plate. SEM observation at magnification $\times 100$ to $\times 300$ showed that with the increase of HA content, the attached cell number was reduced, exposing the unoccupied cell-free space on the plate surface (Figure 6A). At higher magnification $(\times 1000)$, the spreading of the adherent cells was slightly inhibited on the plate with $10 \%$ HA (Figure 6B). With the increase of HA, both the viable cell number and $\mathrm{O}_{2}{ }^{-}$production were reduced (Figure 6C). However, following precoating with fibronectin, the reduction of cell proliferation became less pronounced (right column in Figure 6C).

We investigated the possibility that growth inhibitory factor(s) are released from the HA-dispersed Ti-based composite plate. The sintered Ti plates with different HA contents were dipped in cell culture medium and incubated for $24 \mathrm{~h}$ in an $\mathrm{CO}_{2}$ incubator, and the culture medium was collected. Cell suspensions, prepared by trypsinization, were cultured with the collected medium and viable cell number was measured. The cultured medium prepared in the presence of up to $10 \%$ HA did not significantly affect the cell growth (Figure 7A). When the culture medium and cell suspension were incubated on fibronectin-coated culture plates, the increase of HA content again did not significantly affect cell growth, but slightly reduced the $\mathrm{O}_{2}^{-}$production (Figure $7 \mathrm{~B}$ ).

The effect of eluted factor from the HA powder on cell proliferation was next investigated. The elution factor from HA powder (100\%) slightly, but significantly reduced cell growth while the eluate from the mixed sample of Ti and HA powders (HA content; 5 10\%) did not affect cell growth (Figure 8). Similar results were obtained with fibronectincoated plates (right column in Figure $8 \mathrm{~B}$ ). This suggests the superiority of mixing $\mathrm{Ti}$ and HA powders over HA powder. 


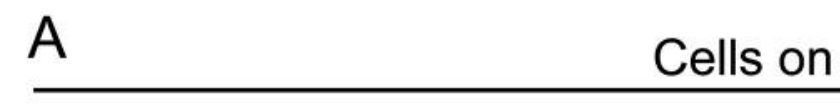

x300
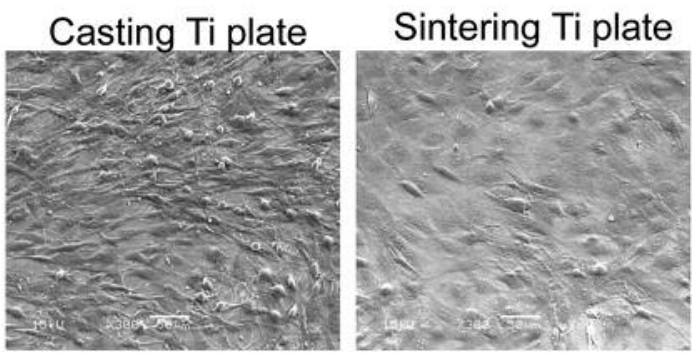

Pure Ti plate
coated with
Sintering Ti plate coated with fibronectin fibronectin
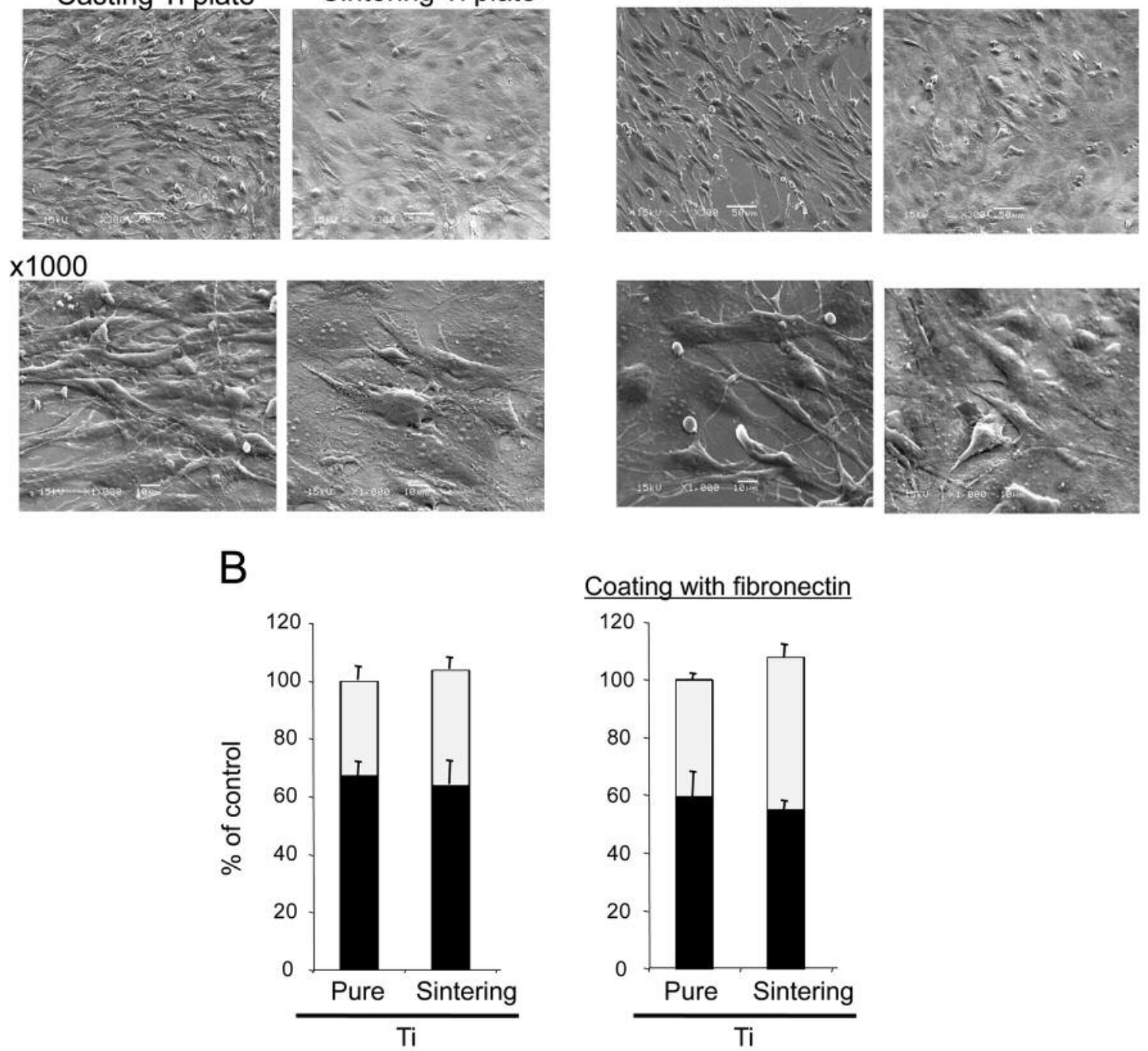

Figure 5. Comparison between pure Ti and sintering Ti on the adhesion/proliferation of MC3T3-E1 cells. (A) SEM images showing cells cultured on the Ti plates (left) and fibronectin-coated Ti plates (right). (B) Viable cell number was determined from the absorbance values obtained by WST-1 assay and is represented as \% of control. The white columns represent $\mathrm{O}_{2}^{-}$production, black columns represent proliferation of MC3T3-E1 cells. Values are mean \pm SE for 5 wells. The reproducibility was confirmed by one additional experiment.

Effect of sintering heat of HA on growth of MC3T3. Since the elution factor from the Ti/HA plate was not responsible for suppressing the proliferation of MC3T3-E1 cells, the possibility that the properties of HA on the plate surface may be involved in suppressing cell proliferation was investigated. When the sintering temperature of HA was increased from $500^{\circ} \mathrm{C}$ to $1100^{\circ} \mathrm{C}$, the surface of the plate became finer, some portion melted at $1100^{\circ} \mathrm{C}$ (Figure 9A).
Cells were hardly adhered on $\mathrm{HA}$ sintered at $500^{\circ} \mathrm{C}$ and $800^{\circ} \mathrm{C}$, while increased numbers of adherent cells were observed on HA sintered at $1100^{\circ} \mathrm{C}$ (Figure 9B). However, adhesion and proliferation were considerably variable from site to site of the plates, as shown in SEM images.

Proliferative properties of MC3T3-E1 cells on carbonatecontaining apatite. Next, the proliferation of MC3T3-E1 cells 

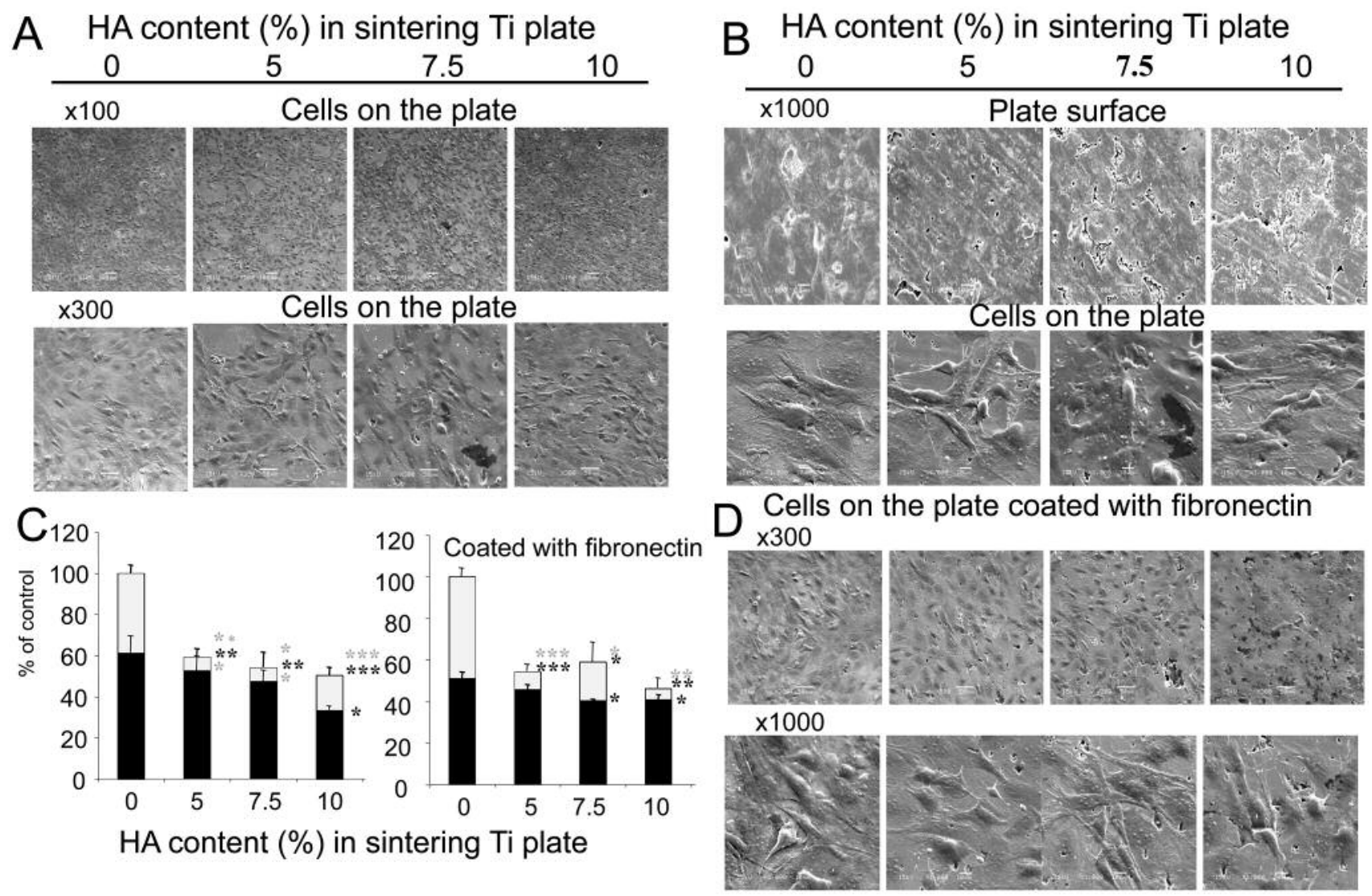

Figure 6. Proliferation of MC3T3-E1 cells on sintering Ti plate containing HA. (A) SEM image $(\times 100, \times 300)$ of cells on the Ti plate. (B) SEM images $(\times 1000)$ show the surface shape of Ti plate containing HA (upper panels), and adhesive cells on the plate (lower panels). (C) The proliferation of MC3T3-E1 cells on plates was quantitatively evaluated by the WST-1 assay. White area in columns represents $\mathrm{O}_{2}^{-}$production and black columns represent proliferation of cells. Values are mean $\pm S E$ for 5 wells. The reproducibility was confirmed by one additional experiment. $* p<0.05, * * p<0.01, * * * p<0.001$ vs. the corresponding control group. (D) SEM image (x300, x1000) of cells on the fibronectin-coated Ti plate.

cultured on carbonate-containing apatite, which is considered to be closer to the apatite in the living body than HA, was investigated. The cells were found to proliferate on the carbonate-containing apatite as thin layers observable through apatite particles under the phase contrast microscope (Figure 10A). Under observation with SEM, the cells can be seen adhered to apatite more clearly, and on the fibronectin-coated apatite, adhered cells appeared to be more active (Figure 10B).

SOD treatment did not apparently change the morphology of the cells, as compared with control cells cultured on plastic dish (Figure 10C). Culturing on the carbonatecontaining apatite significantly promoted proliferation of MC3T3-E1 cells, and pre-coating of the plate with fibronectin further enhanced the proliferation (Figure 10D).

\section{Discussion}

Currently, $\mathrm{Ti}$ is the most popular material for dental implants. However, it has been reported to contain amorphous layers of collagen fibrils (5) and proteoglycans (6) at the contact site with the bone tissue. Recent HA-coating technology on $\mathrm{Ti}$ surface (8) improved the bonding between $\mathrm{Ti}$ and bone tissue (1-3). HA is an inorganic component of bones and teeth. Sintered body of HA has been applied to implants (7). Osteoblasts actively proliferate on the surface and directly bond to the bones (14), and replaced with new bone. However, coated HA may be peeled off from the implantation site or some substances may be eluted from $\operatorname{HA}(10,11)$.

As an alternative to HA coating on the Ti surface, we manufactured a Ti/HA material by mixing the Ti and HA powders, solidifing and sintering them at $1100^{\circ} \mathrm{C}$ by compression shear method (15). X-ray diffraction showed that the compressive load of $500 \mathrm{MPa}$ and shearing stress (distance 1 to $10 \mathrm{~mm}$ ) can be applied without altering the original characteristics of HA during the manufacturing process (Figure 1A). HA was stable at $800^{\circ} \mathrm{C}$, and some part of it was decomposed at $1100^{\circ} \mathrm{C}$ (Figure 1B). Hydroxyl group is produced above $1000^{\circ} \mathrm{C}$, while tricalcium phosphate 

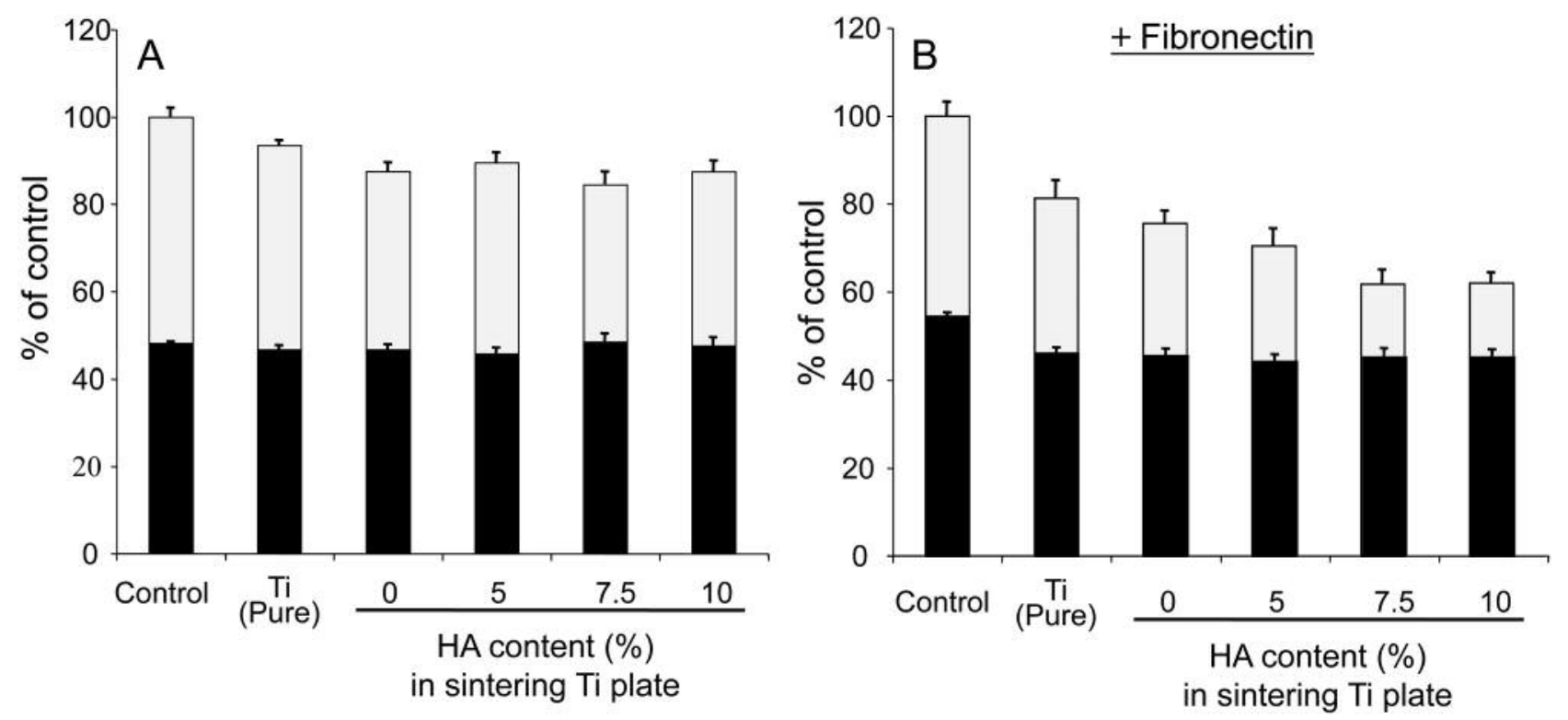

Figure 7. Effect of soluble factor from sintering Ti plate containing HA on the proliferation of MC3T3-E1 cells. (A) Sample plates were incubated with culture medium at $37^{\circ} \mathrm{C}$ for $24 \mathrm{~h}$. The incubation medium was centrifuged at $1700 \times \mathrm{g}$ for $10 \mathrm{~min}$, and the supernatant was mixed with cell suspension (final cell density: $4 \times 10^{4}$ cells $/ \mathrm{ml}$ ). Cells were incubated at $37^{\circ} \mathrm{C}$ in $5 \% \mathrm{CO}_{2}$ for $72 \mathrm{~h}$. (B) Cells prepared by the same method were seeded on the fibronectin-coated culture plate. The proliferation of MC3T3-E1 cells was evaluated by the WST-1 assay. Values are mean \pm SE for 5 wells. The reproducibility was confirmed by one additional experiment.

(TCP) and $\mathrm{CaO}$ are generated at $1300^{\circ} \mathrm{C}(15)$. The surface analysis by EPMA revealed that the distribution of $\mathrm{P}$ (a component of HA) coincided with that of HA (Figure 2), but did not coincide with that of $\mathrm{Ca}$. The reason for the differential distribution is not known.

WST-1 reagent is used by many investigators to determine the proliferative capacity of MC3T3-E1 cells. Since this reagent reacts also with $\mathrm{O}_{2}{ }^{-}$in addition to the electronbinding reagent reduced by the mitochondrial succinatetetrazolium reducing system (13) (Figure 3), $\mathrm{O}_{2}^{-}$production can be determined by simultaneous addition of SOD. It is known that MC3T3-E1 cells produce and release $\mathrm{O}_{2}^{-}$(16), and therefore the released $\mathrm{O}_{2}^{-}$can be scavenged by the addition of SOD which cannot penetrate into the cells (Figures 4 and 5). We found that the inclusion of 5\% HA into the Ti/HA significantly reduced $\mathrm{O}_{2}^{-}$(Figure $6 \mathrm{C}$ ). The fact that the reduction of $\mathrm{O}_{2}^{-}$production by the cells can be seen even in the absence of growth inhibition suggests that it may be due to the direct action of HA. Alternatively, HA might have adsorbed $\mathrm{O}_{2}^{-}$by its nonspecific adsorbing property (17). Considering that the MC3T3-E1 cells adhere and proliferate on both Ti pure and sintering plates to comparable extent (Figure 5B), the surface textures of both plates may be almost identical with each other.

The adhesion and proliferation of MC3T3-E1 cells on the $1100^{\circ} \mathrm{C}$ sintered $\mathrm{Ti} / \mathrm{HA}$ was dose-dependently reduced with the increase in the HA content (Figure 6C). This result is contradictory to the general concept that HA has good affinity for osteoblasts. The growth inhibition by HA may not be due to inhibitory substance(s) eluted from composite, since medium conditioned with the composites had no effect on growth (Figure 7). We found that cell adherence on the HA plates sintered at 500 and $800^{\circ} \mathrm{C}$ was hardly discernible (Figure 9). HA at sintering temperatures of 500 and $800^{\circ} \mathrm{C}$ showed similar waveform with standard non-heated HA powder (Figure 1B). These results suggest that both HA powder and HA sintered at 500 and $800^{\circ} \mathrm{C}$ strongly inhibit adhesion and proliferation of MC3T3-E1 cells. However, when the sintering temperature was elevated up to $1100^{\circ} \mathrm{C}$, HA may be partially decomposed, and partial melt-down of the surface of the HA plate can generate uneven cell adhesion/proliferation foci on the plate (Figure 9B). These data suggest that at $1100^{\circ} \mathrm{C}, \mathrm{HA}$ begins to decompose unevenly where cells can adhere and proliferate, whereas at the site of intact HA, cell adhesion is strongly inhibited. Normal human osteoblasts adhere and stretch well on the Ti site of Ti/HA complexes prepared by sintering at $1200^{\circ} \mathrm{C}$ for $3 \mathrm{~h}$, avoiding the HA site (18). This finding is in good agreement with our finding that the occupancy of the porous portion was increased on the plate surface, with the increase in HA content. Thus, this porous portion may be the site of HA, and that MC3T3-E1 avoid this porous site (Figure 6B). Addition of HA nanoparticles to rat primary osteoblasts has been reported to inhibit cell 


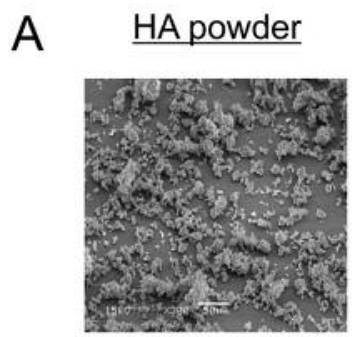

$\times 300$

Ti powder

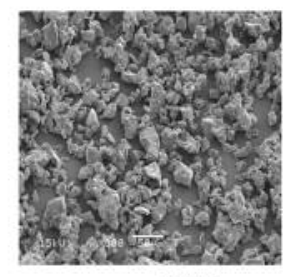

$\times 300$

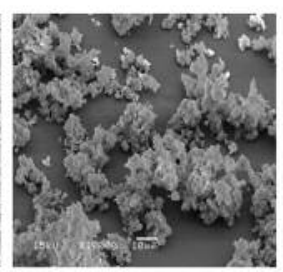

$\times 1000$

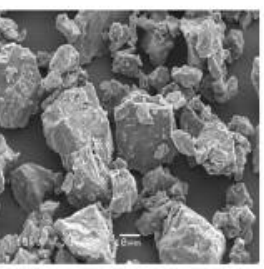

$\times 1000$

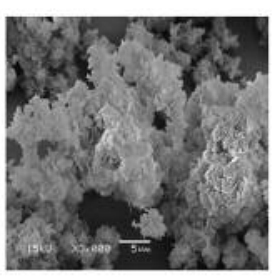

$\times 3000$

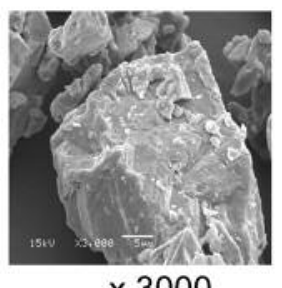

B
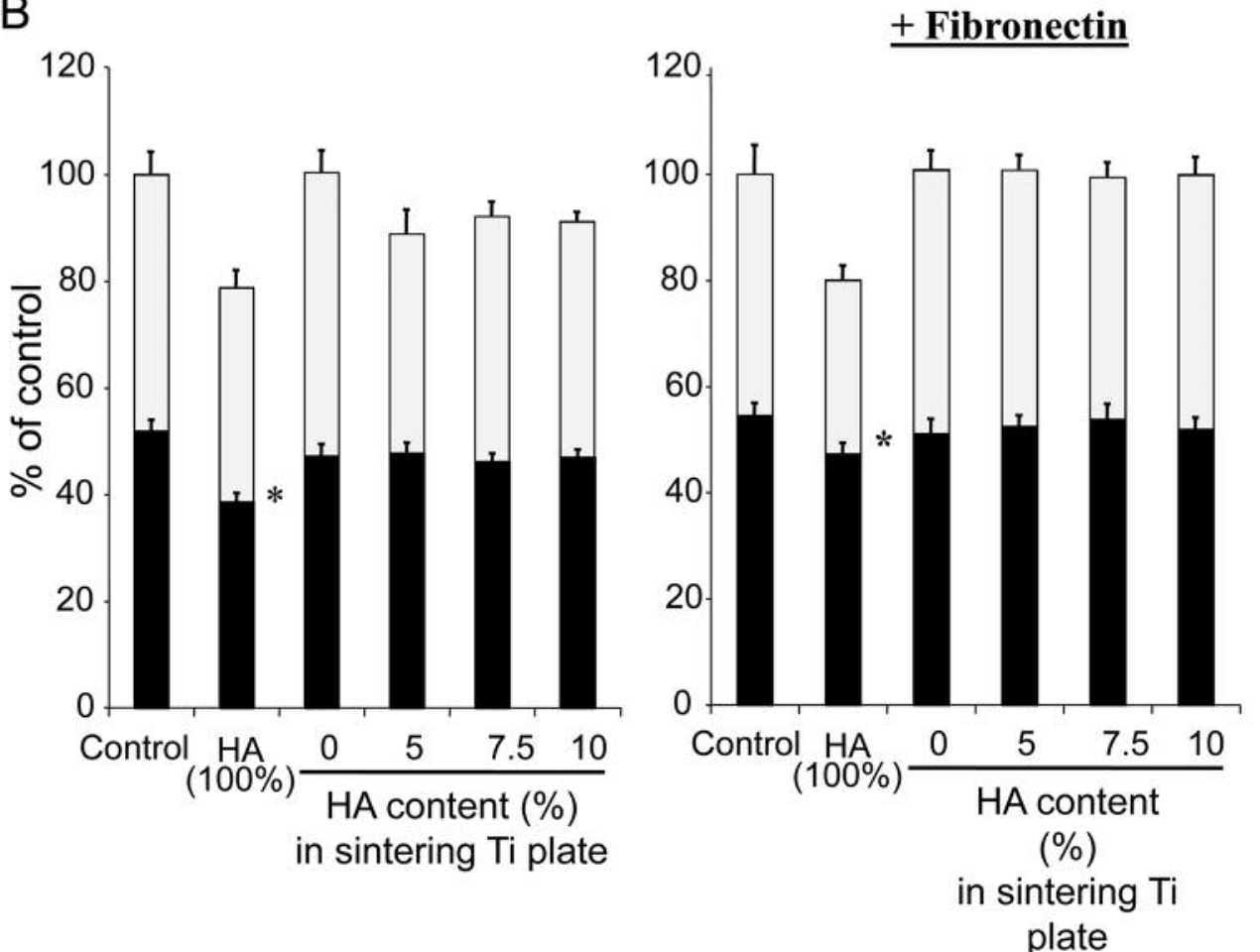

Figure 8. Effect of soluble factor from HA powder and Ti powder on the proliferation of MC3T3-E1 cells. (A) SEM image of HA powder and Ti powder. (B) The cells were seeded on the HA plate (left panels) and fibronectin-coated culture plate (right panels). The proliferation of MC3T3-E1 cells was evaluated by WST-1 assay. ${ }^{*} p<0.05$ vs. the corresponding control group.

proliferation in a concentration-dependent manner, by induction of apoptosis via the mitochondrial pathway accompanied by the elevation of p53 and cytochrome c, and the extent of apoptosis induction correlated to the shape and size of the nanoparticles (19).
The question that arises is which element is necessary for HA to promote cell adhesion? Serum protein that contains Arg-Gly-Asp (RGD) sequence has been reported to play an important role in regulating the attachment and extension of the cells to HA, but is not essential for the binding of Ti to 
A
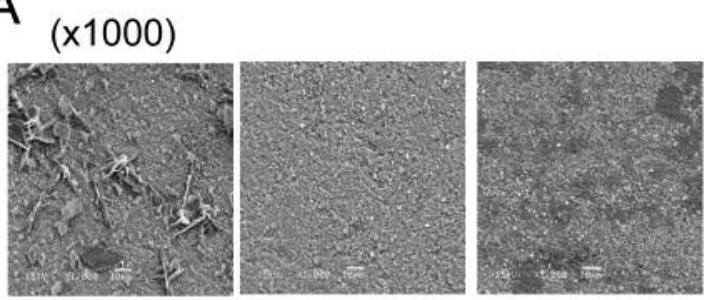

(x5000)
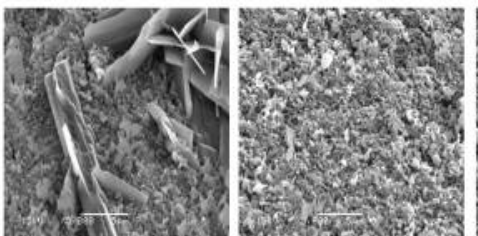

$500^{\circ} \mathrm{C}$

$800^{\circ} \mathrm{C}$

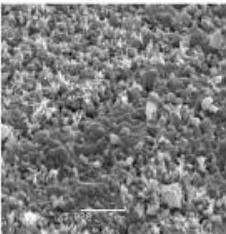

$1100^{\circ} \mathrm{C}$

Sintering temperature of HA plate

B
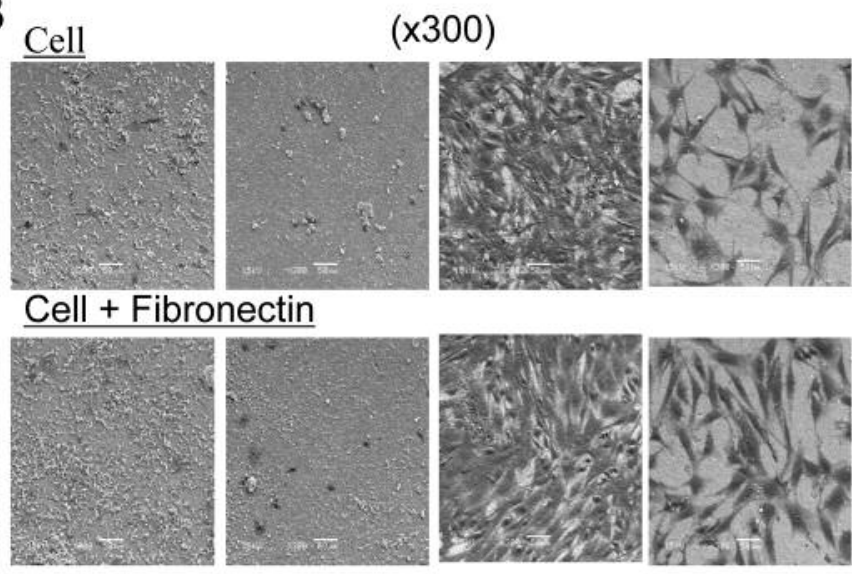

Cell
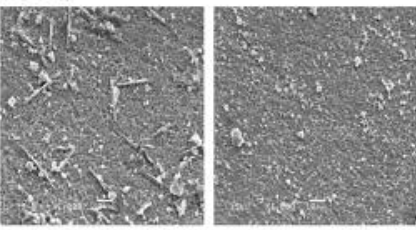

$(\mathrm{x} 1000)$

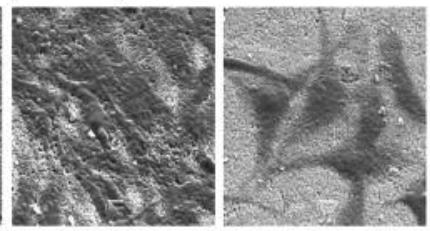

Cell + Fibronectin

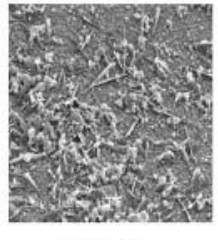

$500^{\circ} \mathrm{C}$

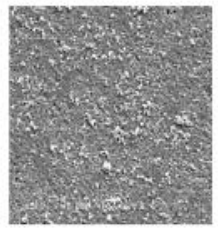

$800^{\circ} \mathrm{C}$

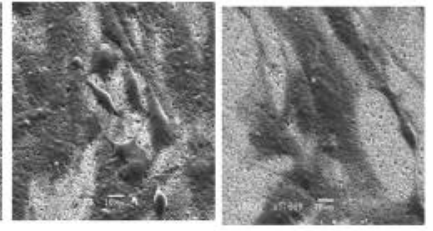

$1100^{\circ} \mathrm{C}$

Figure 9. Effect of sintering temperature of HA plate on the adhesion/proliferation of MC3T3-E1 cells. (A) SEM images $(\times 1000, \times 5000)$ show the surface shape of sintering HA plates. (B) SEM images $(\times 300, \times 1000)$ of cells cultured on the HA plates and on the fibronectin-coated HA plates. The cells cultured on $1100^{\circ} \mathrm{C}$-sintered HA show crammed and sparse area.

the cells (20). It is possible that when HA shows inhibitory effects on cell proliferation, the adhesion protein containing the RGD sequence may not bind to the cell surface. Since cell adhesion is essential for the subsequent cell proliferation and differentiation, inhibition of adhesion may result in cell death. Precoating of the plates with fibronectin relieved the growth inhibitory action of HA against MC3T3-E1 cells to some extent in the Ti/HA plate (Figure 6C), while it remarkably stimulated growth on carbonated apatite (Figure 10D). Fibronectin is a dimeric glycoprotein that constitutes the extracellular matrix $(21,22)$, and the RGD sequence of fibronectin recognizes integrin $\alpha 5 \beta 1$ and $\alpha \mathrm{V} \beta 3$ on the cell membrane to allow cell attachment. Both integrins are reported to be involved in the adhesion of MC3T3-E1 cells to the RGD peptides of fibronectin (23). Higher concentrations of fibronectin may be necessary to improve adhesion and growth of MC3T3-E1 cells on sintered Ti/HA plate at $1100^{\circ} \mathrm{C}$.
At present, HA-coated implants which show high affinity to bone tissue are manufactured by plasma spraying method that bakes HA powder on the $\mathrm{Ti}$ surface at ultra-high temperature $\left(13,000^{\circ} \mathrm{C}\right)$ and ultra-high speed (24). When the temperature exceeds $1000^{\circ} \mathrm{C}$, hydroxyl groups in HA are eliminated and decomposition of HA proceeds, generating several decomposition products including TCP. On the other hand, proliferation of MC3T3-E1 cells was markedly stimulated on carbonate-containing apatite (considered to be close to the apatite present in the living body), and stimulation was further enhanced by fibronectin coating, in quite different fashion from HA. Carbonate apatite has been reported to be superior to octacalcium phosphate in promoting growth and differentiation markers of MC3T3-E1 cells (25).

In conclusion, the present study suggests that HA itself inhibits the growth of osteoblastic cells, but sintering at $1100^{\circ} \mathrm{C}$ changes the surface properties of the composite so as to stimulate the cell growth. 


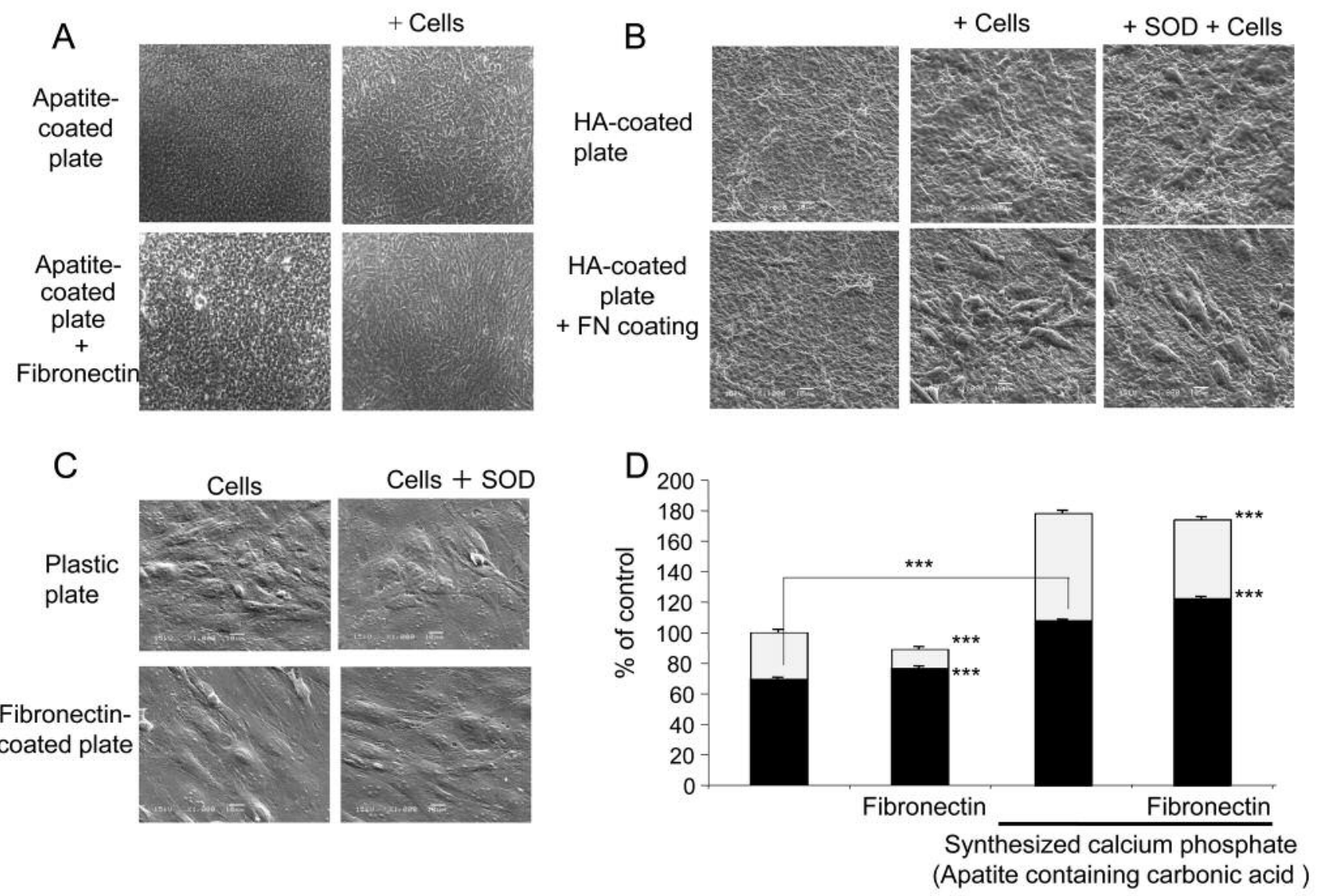

Figure 10. Effect of synthesized calcium phosphate (apatite containing carbonic acid) on the adhesion/proliferation of MC3T3-E1 cells. (A) Phase contrast image. Shape of apatite containing carbonic acid (upper panel), and MC3T3-E1 cells cultured on fibronectin-coated plates (lower panel). Lower panels show the image of fibronectin-coated apatite. (B) SEM images ( $\times 1000)$ of HA-coated plate and fibronectin-coated plate (lower panel). (C) SEM images $(\times 1000)$ of cells cultured on normal culture dish.(D) Proliferation of MC3T3-E1 cells was evaluated by the WST-1 assay. Values are mean \pm SE for 5 wells. The reproducibility was confirmed by one additional experiment. ${ }^{* *} p<0.001$ vs. the corresponding control group.

\section{Conflicts of Interest}

The Authors wish to confirm that there are no conflicts of interest associated with this publication and there has been no significant financial support for this work that could have influenced its outcome.

\section{Authors' Contributions}

Kobayashi M performed all the experiment and wrote the paper. Nihonmatsu S, Okawara T and Onuki $\mathrm{H}$ contributed in some part of the experiments. Sakagami $H$, Nakajima $H$, Takeishi $H$ and Shimada $\mathbf{J}$ gave the experimental idea and suggestions for the experiments.

\section{Acknowledgements}

The Authors thank Prof. Shin K, Meikai University School of Dentistry for valuable discussion, and Dr. Kunii S, Dr. Kanda Y and Dr. Tajima
M, Meikai University School of Dentistry for technical asistance. This work was supported in part by Onuki General Foundation.

\section{References}

1 Hedia HS and Mahmoud NA: Design optimization of functionally graded dental implant. Biomed Mater Eng 14(2): 133-143, 2004. PMID: 16025465. DOI: 10.1002/jbm.b.30275

2 Lavos-Valereto IC, Wolynec S, Deboni MC and König B Jr.: In vitro and in vivo biocompatibility testing of Ti-6Al-7 Nb alloy with and without plasma-sprayed hydroxyapatite coating. J Biomed Mater R 58(6): 727-733, 2001. PMID: 11745527.

3 Strnad Z, Strnad J, Povýsil C and Urban K: Effect of plasmasprayed hydroxyapatite coating on the osteoconductivity of commercially pure titanium implants. Int J Oral Maxillofac Implants 15(4): 483-490, 2000. PMID: 10960980.

4 Brånemark PI, Adell R, Breine U, Hansson BO, Lindström J and Ohlsson A: Intra-osseous anchorage of dental prostheses. I. Experimental studies. Scand J Plast Reconstr Surg 3: 81-100, 1969. PMID: 4924041. 
5 Listgarten MA, Buser D, Steinemann SG, Donath K, Lang NP and Weber HP: Light and transmission electron microscopy of the intact interfaces between non-submerged titanium-coated epoxy resin implants and bone or gingiva. J Dent Res 71: 364 371, 1992. PMID: 1556294. DOI: 10.1177/0022034592071 0020401

6 Ayukawa Y, Takeshita F, Inoue T, Yoshinari M, Ohtsuka Y, Mura, K, Shimono $M$, Suetsugu $T$ and Tanaka $T$ : An ultrastructural study of the bone-titanium interface using pure titanium-coated plastic and pure titanium rod implants. Acta Histochem Cytochem 29: 243-254, 1996.

7 Monroe EA, Votava W, Bass DB and McMullen J: New calcium phosphate ceramic material for bone and tooth implants. J Dent Res 50: 860-861, 1971. PMID: 5283245. DOI: 10.1177/ 00220345710500041201

8 Neo M, Kotani S, Nakamura T, Yamamuro T, Ohtsuki C, Kokubo T and Bando Y: A comparative study of ultrastructures of the interfaces between four kinds of surface-active ceramic and bone. J Biomed Mater Res 26: 1419-1432, 1992. PMID: 1447227. DOI: $10.1002 / \mathrm{jbm} .820261103$

9 Zablotsky MH: Hydroxyapatite coatings in implant dentistry. Review. Implant Dent 1(4): 253-257, 1992. PMID: 1298500.

10 Yamamoto $\mathrm{H}$, Shibata Y, Tachikawa $\mathrm{T}$ and Miyazaki T: In vivo performance of two different hydroxyapatite coatings on titanium prepared by discharging in electrolytes. J Biomed Mater Res B Appl Biomater 78(1): 211-214, 2006. PMID: 16362960. DOI: $10.1002 / \mathrm{jbm} . b .30477$

11 Ogiso M, Yamamura M, Kuo PT, Borgese D and Matsumoto T: Comparative push-out test of dense HA implants and HA-coated implants: findings in a canine study. J Biomed Mater Res 39(3): 364-372, 1998. PMID: 9468044.

12 Ishiyama M, Miyazono Y, Sasamoto K, Ohkura Y and Ueno K: A highly water-soluble disulfonated tetrazolium salt as a chromogenic indicator for NADH as well as cell viability. Talanta 44: 1299-305, 1997. PMID: 18966866.

13 Ukeda H, Shimamura T, Tsubouchi M, Harada Y, Nakai Y and Sawamura M: Spectrophotometric assay of superoxide anion formed in Maillard reaction based on highly water-soluble tetrazolium salt. Anal Sci 18: 1151-1154, 2002. PMID: 12400664.

14 Ong JL, Hoppe CA, Cardenas HL, Cavin R, Carnes DL, Sogal A and Raikar GN: Osteoblast precursor cell activity on HA surfaces of different treatments. J Biomed Mater Res 39(2): 176183, 1998. PMID: 9457545.

15 Takeishi H, Nakayama $\mathrm{N}$ and Miki H: Consolidation with grain refinement by compression shearing method under room temperature. J Soc Mat Sci Japan 54(3): 233-238, 2005.

16 Gasbarrini A, Grigolo B, Serra M, Baldini N, Scotlandi K, Gasbarrini A, Bernardi M and Facchini A: Generation of free radicals during anoxia and reoxygenation in perfused osteoblastlike cells. Clin Orthop Relat Res 338: 247-252, 1997. PMID: 9170387.
17 Niwa M, Li W, Sato T, Daisaku T, Aoki H and Aoki H: The adsorptive properties of hydroxyapatite to albumin, dextran and lipids. Biomed Mater Eng 9: 163-169, 1999. PMID: 10572620.

18 Oguchi H, Watazu A, Karube Y, Ohshima T, Maeda N, Nonami $\mathrm{T}$ and Morita M: Response of normal human osteoblast cells to titanium and hydroxyapatite on titanium/hydroxyapatite composites. Tsurumi Univ Dent J 30: 127-132, 2004 in Japanese.

$19 \mathrm{Xu} \mathrm{Z}$, Liu C, Wei J and Sun J: Effects of four types of hydroxyapatite nanoparticles with different nanocrystal morphologies and sizes on apoptosis in ratosteoblasts. J Appl Toxicol 32: 429-435, 2012. PMID: 22162110. DOI: 10.1002/jat.1745

20 Okamoto K, Matsuura T, Hosokawa R and Akagawa Y: RGD peptides regulate the specific adhesion scheme of osteoblasts to hydroxyapatite but not to titanium. J Dent Res 77: 481-487, 1998. PMID: 9496921. DOI: $10.1177 / 00220345980770030701$

21 Pankov R and Yamada K: Fibronectin at a glance. J Cell Science 115(Pt 20): 3861-3863, 2002. PMID: 12244123.

22 Mao Y and Schwarzbauer JE: Fibronectin fibrillogenesis, a cellmediated matrix assembly process. J Int Soc Matrix Biol 24: 389399, 2005. PMID: 16061370. DOI: 10.1016/j.matbio.2005.06.008

23 Lee MH, Adams CS, Boettiger D, Degrado WF, Shapiro IM, Composto RJ and Ducheyne P: Adhesion of MC3T3-E1 cells to RGD peptides of different flanking residues: detachment strength and correlation with long-term cellular function. J Biomed Mater Res A 81: 150-160, 2007. PMID: 17111408. DOI: 10.1002/jbm.a.31065

24 Kato R, Nakamura S, Katayama K and Yamashita K: Electrical polarization of plasma-spray-hydroxyapatite coatings for improvement of osteoconduction of implants. J Biomed Mater Res A 74(4): 652-658, 2005. PMID: 16021619. DOI: 10.1002/ jbm.a.30339

25 Wang J, de Boer J and de Groot K: Proliferation and differentiation of osteoblast-like MC3T3-E1 cells on biomimetically and electrolytically deposited calcium phosphate coatings. J Biomed Mater Res A 90: 664-670, 2009. PMID: 18563812. DOI: 10.1002/ jbm.a.32128
Received March 21, 2019

Revised April 26, 2019

Accepted May 2, 2019 